\title{
MENONTON VIDEO KONTEN DEWASA BAGI SUAMI ISTRI
}

\author{
Zuhriah, S. HI,. MH. \\ Pengadilan Agama Nunukan, Kalimatan Utara \\ Zuhriah.haririe@gmail.com
}

\section{Abstrak}

Bagi pasangan suami istri, hubungan intim adalah sesuatu yang biasa dan wajib dilakukan. Para peneliti dan dokter kesehatan, baik dari Eropa dan Amerika atau bahkan Indonesia menyatakan bahwa semakin sering pasangan melakukan hubungan intim maka semakin baik dan semakin sehat. Disisi lain juga berhunbungan intim ini juga menjadikan pasangan lebih harmonis dan bahagia, bahkan seorang suami mungkin akan hilang gairahnya seksualnya terhadap wanita lain karena telah merasa cukup dengan pasangan sah-nya. Namun terkadang beberapa pasangan merasa jemu dengan cara, metode ataupun gaya dalam berhubungan. Sehingga tidak jarang mencari referensi lain untuk meraih kepuasan biologis dalam berhubungan. Maka cara termudah adalah dengan menonton film dewasa dari internet atau kaset yang didapatkan dari para penjual ilegal. Hal ini menjadi sesuatu yang baru dan mungkin tidak pernah terjadi pada masa-masa terdahulu sehingga secara sederhananya menjadi bahan perbincangan antara ahli fikih kontemporer. Berdasar hasil yang diperoleh dari beberapa literasi, umumnya para ulama berpebdapat tentang haramnya menonton video dewasa walaupun bersama istri sekalipun. 
Keyword: Nonton, Film Dewasa, Suami Istri.

\section{A. Latar Belakang Masalah}

Agama Islam merupakan agama samawi yang menyempurnakan ajaran agama-agama samawi sebelumnya. Ajaran Islam diyakini sebagai ajaran yang membawa manusia kepada keselamatan di dunia dan di akhirat. Ajaran Islam tidak hanya membahas mengenai hubungan manusia dengan pencipta-nya, yaitu Allah Swt. melainkan juga membahas mengenai hubungan manusia dengan manusia, makhluk hidup dan alam sekelilingnya.

Ajaran Islam dalam membahas mengenai pola-pola hubungan tersebut terbagi atas dua ilmu yaitu pertama, (الغيب yakni ilmu mengenai hal-hal yang bersifat gaib, abstrak, atau ruhaniah yang biasa diistilahkan dengan ilmu metafisika. Kedua, ( العلم الثهادة yakni ilmu mengenai hal-hal yang bersifat ada dan konkret yang biasa disebut dengan ilmu fisika. ${ }^{1}$ Wilayah al-'ilmu al-syahādat inilah yang secara konkret dapat dijangkau oleh pengetahuan manusia secara keseluruhan. Ilmu fisika ( العلم الثهادة ) dapat dikategorikan menjadi tiga bidang kajian yaitu pertama, العقيدة, keyakinan/ keimanan yang dikaji oleh ushuluddin. Kedua, الثريعة, hukum Allah mengenai perintah dan larangan-Nya yang dikaji oleh ilmu syariah. Ketiga, الاخلاق, etika, tata krama, atau tingkah laku baik dan buruk dalam masyarakat yang dikaji oleh ilmu adab dan humaniora. Pada kesempatan kali ini, penulis akan mefokuskan kajian hanya dalam satu bidang saja yaitu mengenai hukum Allah swt. mengenai halal atau haram.

Syariah sebagai salah satu cabang ilmu agama Islam memiliki kajian yang cukup luas yang menyangkut segala tingkah laku manusia baik dalam pola hubungannya dengan Allah swt., maupun hubungannya dengan manusia dan alam

${ }^{1}$ QS. Al-Mumtahāānah/60: 22.

Sangaji Jurnal Pemikiran Syariah dan Hukum 
sekitarnya. Kajian ilmu syariah terbagi lagi atas dua bidang yaitu ibadah dan muamalah. Kedua bidang ini memiliki ruang lingkup yang berbeda sehingga memunculkan kaidah-kaidah yang berbeda pula. Namun terkadang bagi masyarakat awam, kaidah ilmu syariah tidak mampu dibedakan penggunaannya pada kedua bidang tersebut. Salah satu kaidah yang sangat populer yaitu:

\section{الاصل فى العبادة التحريم والبطل إلا ما جاء به الد ليل أوامره}

Maksudnya:

"Hukum asal dalam beribadah adalah haram dan batal kecuali ada dalil yang memerintahkannya."

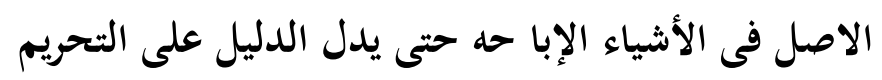

Maksudnya:

"Hukum asal dari sesuatu (muamalah) adalah mubah sampai ada dalil yang melarangnya (memakruhkan atau mengharamkannya)."2

Bila ditinjau dari aspek pembidangan hukum Islam, maka membahas mengenai hubungan suami dan istri merupakan bidang muamalah yang di bahas dalam fikih munakahat (pernikahan). Oleh karena itu, pembahasan mengenai hal-hal yang berhubungan dengan aktivitas pasangan suami istri baik secara lahir maupun batin bisa dikatakan masuk pada ranah muamalah sehingga berlaku kaidah" hukum asal dari sesuatu (muamalah) adalah mubah sampai ada dalil yang melarangnya (memakruhkan atau mengharamkannya)."

Di era modern sekarang ini, aktivitas manusia cenderung mengikuti arus perkembangan informasi dan teknologi. Banyak kegiatan yang dimudahkan dengan bantuan

${ }^{2}$ Imam As-Suyuthi, al-Asyba' wan nhadhair (t.t.: t.tp, t.th.), h. 43. 
teknologi. Perkembangan fotografi dan sinematografi yang semakin bebas dalam menampilkan kreativitas manusia, termasuk dalam menggambarkan pola hubungan laki-laki dan perempuan mulai dari sekedar perasaan cinta kasih hingga pada aktivitas yang intim. Semakin banyak video intim yang beredar, baik di internet maupun di tayangan televisi.

Secara umum, para ulama fikih secara tegas mengharamkan tontonan yang membangkitkan syahwat. Namun bagaimana jika tontonan tersebut dinikmati oleh sepasang suami istri dengan beberapa alasan tertentu? Tulisan ini mencoba untuk menjelaskan perihal tersebut yang pada era kontemporer menjadi polemik tersendiri bagi kehidupan umat Islam. Maka dari latar belakang tersebut, dapat dirumuskan beberapa sub masalah, antara lain sebagai berikut; apa saja dalil-dalil mengenai hubungan suami istri dikaitkan dengan tontonan dewasa, bagaimana pandangan ulama mengenai suami istri yang menonton video dewasa, Dan bagaimana kedudukan hukum bagi pasangan suami istri yang menonton video dewasa?.

\section{B. Dalil-dalil yang Berkaitan dengan Aktivitas Suami Istri dan Tontonan Dewasa}

Pembahasan mengenai dalil-dalil aktivitas suami istri dan tontonan dewasa terlebih dahulu di awali dengan mengetahui secara jelas pengertian masing-masing. Suami istri secara bahasa yaitu pasangan laki-laki dan perempuan yang telah menikah. ${ }^{3}$ Aktivitas pasangan suami istri secara bahasa yaitu segala jenis kegiatan dari seorang laki-laki dan perempuan yang telah terikat hubungan pernikahan. Secara istilah sesuai dengan maksud makalah ini yaitu berbagai jenis

3 Kementerian Pendidikan dan Kebudayaan RI, Aplikasi Kamus Besar Bahasa Indonesia Edisi Kelima (Jakarta: Badan Pengembangan dan Pembinaan Bahasa Kemendikbud, 2016).

Sangaji Jurnal Pemikiran Syariah dan Hukum 
kegiatan yang halal dan boleh dilakukan oleh seorang laki-laki dan seorang perempuan yang telah terikat hubungan pernikahan. Apabila sebelum pernikahan beberapa hal dilarang dan diharamkan dilakukan oleh pasangan tersebut, namun setelah pernikahan larangan tersebut dibolehkan.

Adapun mengenai video dewasa terdiri atas dua kata yaitu video dan dewasa. Video secara bahasa yaitu bagian yang memancarkan gambar pada pesawat televisi atau rekaman gambar hidup atau program televisi untuk ditayangkan lewat pesawat televisi. ${ }^{4}$ Sedangkan dewasa yaitu dewasagrafi atau cabul. ${ }^{5}$ Dewasagrafi (Ar.: tabarruj atau 'āriyah) berasal dari bahasa Yunani porne artinya perempuan jalang; graphein artinya menulis. Dewasagrafi adalah bahan yang dirancang dengan sengaja dan semata-mata untuk membangkitkan nafsu birahi (syahwat) dan seks. ${ }^{6}$ Pengertian ini tidak dapat dibatasi hanya sekedar tayangan televisi saja namun seluruh gambar bergerak berupa film, anime, vlog, atau tayangan lainnya yang menampilkan aurat seseorang. Lebih jauh lagi, tayangan tersebut sampai menampilkan aktivitas intim dari laki-laki dan perempuan (boleh jadi dua orang atau lebih) yang mampu membangkitkan syahwat (nafsu birahi). Tayangan dewasa seperti ini dijadikan sebagai media untuk membangkitkan syahwat yang berujung pada kegiatan seksual suami istri.

Terdapat beberapa dalil yang berkaitan dengan pembahasan tersebut antara lain sebagai berikut:

${ }^{4}$ Kementerian Pendidikan dan Kebudayaan RI, Aplikasi Kamus Besar Bahasa Indonesia Edisi Kelima.

5 Kementerian Pendidikan dan Kebudayaan RI, Aplikasi Kamus Besar Bahasa Indonesia Edisi Kelima.

6 Tim Penyusun Ensiklopedia Hukum Islam, Ensiklopedia Hukum Islam 4 (Jakarta: PT. Ichtiar Baru Van Hoeve, 1997), h. 1412. 
1. Dalil Al Qur'an

a) QS. Al Rūm:21

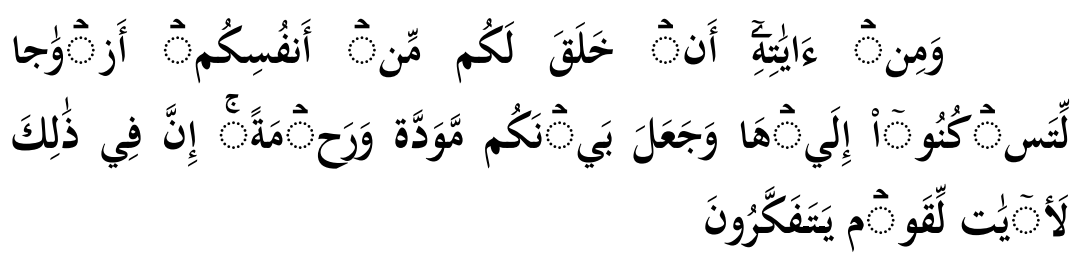

Terjemahnya:

"Dan di antara tanda-tanda (kebesaran)-Nya ialah Dia menciptakan pasangan-pasangan untukmu dari jenismu sendiri, agar kamu cenderung dan merasa tenteram kepadanya, dan Dia menjadikan di antaramu rasa kasih sayang. Sungguh, pada yang demikian itu benar-benar terdapat tanda-tanda (kebesaran Allah) bagi kaum yang berpikir."7

QS. Al Rūm ayat 21 turun untuk memberikan bukti kepada manusia akan kekuasaan dan rahmat Allah swt. Pada ayat tersebut disebutkan kata (أَزْوَاج) yang artinya istri-istri. ${ }^{8}$ Kemudian kata ( أَفُسِكِمُ ) adalah bentuk jamak dari kata nafs yang berarti jenis atau totalitas sesuatu. Pernyataan bahwa pasangan manusia diciptakan dari jenisnya sendiri menjadikan sementara ulama menyatakan bahwa Allah swt. tidak membolehkan mengawini selain jenisnya. Kemudian jenis ini merupakan pasangannya. Hal ini berarti perkawinan antara lain jenis atau pelampiasan nafsu

7 Kementerian Agama RI, Aplikasi Qur'an Kemenag (Jakarta: Lajnah Pentashihan Mushaf Al-Qur'an, 2016)

8 M. Quraish Shihab, Tafsīr Al-Mishbāh volume 10 (Jakarta: Penerbit Lentera Hati, 2009), h. 185.

Sangaji Jurnal Pemikiran Syariah dan Hukum 
seksual melalui makhluk lain, bahkan bukan pasangannya tidak dibenarkan. ${ }^{9}$

b) QS. Al Nūr: 30-31.

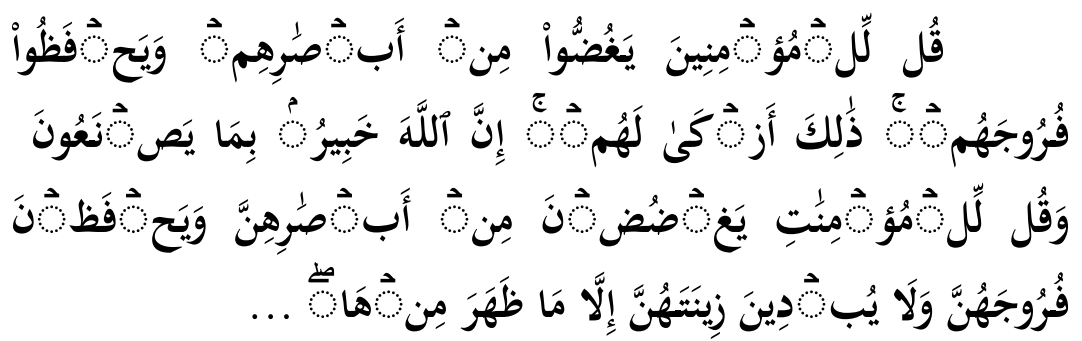

Terjemahnya:

"Katakanlah kepada laki-laki yang beriman, agar mereka menjaga pandangannya, dan memeliharan kemaluannya; yang demikian itu lebih suci bagi mereka. Sungguh, Allah Maha Mengetahui apa yang mereka perbuat. Dan katakanlah kepada para perempuan yang beriman dan memelihara kemaluannya (auratnya), kecuali yang (biasa) terlihat..."10

Kedua ayat ini merupakan kelompok ketiga dari surat Al Nūr yaitu ayat 27 - 34. Kelompok ayat ini berbicara tentang etika kunjung mengunjungi yang merupakan bagian dari tuntunan ilahi yang berkaitan dengan pergaulan sesama manusia. ${ }^{11}$ Diriwayatkan bahwa ayat 27-28 turun berkenaan dengan pengaduan seorang wanita anșar yang berkata: "Wahai Rasulullah, saya di rumah dalam keadaan enggan dilihat oleh seseorang, tidak ayah tidak pula anak. Lalu ayah masuk memenuiku. Ketika beliau masih di rumah, datang lagi

${ }^{9}$ M. Quraish Shihab, Tafsīr Al-Mishbāh volume 10, h. 186.

${ }^{10}$ Kementerian Agama RI, Aplikasi Qur'an Kemenag.

11 M. Quraish Shihab, Tafsīr Al-Mishbāh volume 8 (Jakarta: Penerbit Lentera Hati, 2009), h. 518. 
seorang dari keluarga sedang saya saat itu masih dalam keadaan semula (belum siap bertemu seseorang), maka apa yang harus saya lakukan?" Ayat ini kemudian turun untuk menjawab keluhan ini. ${ }^{12}$

Kemudian ayat selanjutnya yaitu QS. Al Nūr ayat 29 turun berkaitan dengan pertanyaan Abu Bakar AsShiddiq kepada Nabi Muhammad Saw.: "Bagaimana tuntunan Allah Swt. menyangkut kedai-kedai dan penginapan-penginapan yang kita temukan dalam perjalanan kita ke Syam?". ${ }^{13}$ Mengenai QS. An-Nūr ayat 30, Tahir Ibn Asyur menghubungkan ayat ini dengan ayat sebelumnya bahwa setelah menjelaskan ketentuan memasuki rumah, kemudian diuraikan etika ketika telah berada di dalam rumah. Seseorang tidak boleh mengarahkan seluruh pandangannya kepada seluruh bagian rumah kecuali pandangan yang sukar dihindari. ${ }^{14}$

Kemudian Asbabun nuzul QS. Al Nūr ayat 31 sebagaimana diriwayatkan oleh Ibnu Abi Hatim bahwa Asma' binti Murtsad sedang berada di kebun kurmanya. Tiba-tiba beberapa wanita masuk tanpa mengenakan busana hingga terlihat perhiasan di kaki mereka juga dada dan rambutnya. Maka Asma' berkata, "Alangkah buruknya hal ini!", lalu turun ayat ini. Ibnu Jarir meriwayatkan bahwa seseorang wanita memasang dua gelang perak dan mengenakan batu kumala lalu lewat di depan sekelompok orang dan menghentakkan gelang kakinya sehingga mengeluarkan suara. Maka Allah menurunkan ayat "Dan janganlah mereka menghentakkan kakinya agar diketahui perhiasan yang

${ }^{12}$ M. Quraish Shihab, Tafsīr Al-Mishbāh volume 8, h. 518.

${ }^{13}$ M. Quraish Shihab, Tafsìr Al-Mishbāh volume 8, h. 522.

${ }^{14}$ M. Quraish Shihab, Tafsìr Al-Mishbāh volume 8, h. 523-524. 
mereka sembunyikan". ${ }^{15}$ Ayat ini memerintahkan Nabi saw. agar berpesan pula kepada wanita-wanita mukminah agar tidak menampakkan perhiasannya atau bagian tubuhnya yang dapat merangsang laki-laki yang bukan mahramnya. Adapun pernikahan, dijadikan jalan untuk menikmati perhiasan itu secara halal. ${ }^{16}$

Muhammad Ali as-Sayis (ahli tafsir kontemporer asal Mesir) mengatakan bahwa QS. Al Nūr ayat 30-31 sangat terkait dengan ayat 29 surah yang sama yang melarang seseorang memasuki rumah tanpa seizin penghuninya karena diduga akan terlihat sesuatu yang terlarang oleh agama (aurat penghuninya). Selanjutnya Ali as-Sayis mengatakan bahwa sebab turunnya ayat 30 ini adalah kejadian seorang laki-laki yang sedang berjalan di kota Madinah lalu melihat seorang perempuan. Laki-laki tersebut kemudian pergi ke balik dinding dan melihat perempuan itu dari semua sisi. Tanpa sadar hidungnya membentur dinding hingga luka dan berdarah. Ia kemudian melaporkan hal ini kepada Rasulullah saw. setelah menceritakan kisahnya, maka Rasulullah saw. berkata: "Itulah resiko atas dosa yang kamu lakukan." Lalu turun ayat ini yang menyuruh manusia menahan pandangannya untuk tidak melihat sesuatu yang mengundang nafsu birahi (HR. Ibnu Mardawiyyah dari Ali bin Abi Thalib). ${ }^{17}$

\section{Dari Hadis}

15 Al-Qur'an dan Terjemah Al-Kaffah (Surabaya: Sukses Publishing, 2012), h. 354 .

${ }^{16}$ M. Quraish Shihab, Tafsīr Al-Mishbāh volume 8, h. 526.

17 Tim Penyusun Ensiklopedia Hukum Islam, Ensiklopedia Hukum Islam 4, h. 1413. 
Dari Abu Hurairah ra., dari Nabi Muhammad Saw. beliau bersabda:

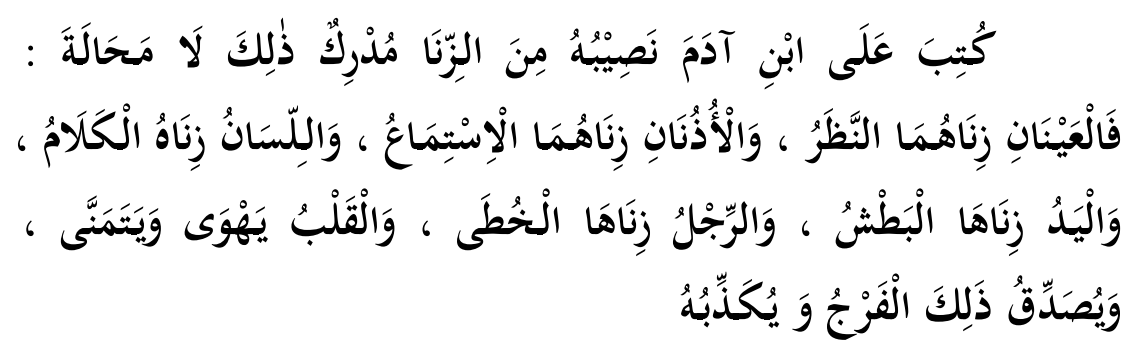

Artinya:

Telah ditentukan atas anak Adam (manusia) bagian zinanya yang tidak dapat dihindarinya: Zina kedua mata adalah melihat, zina kedua telinga adalah mendengar, zina lisan adalah berbicara, zina tangan adalah dengan meraba atau memegang (wanita yang bukan mahram, Pen.), zina kaki adalah melangkah, dan zina hati adalah menginginkan dan berangan-angan, lalu semua itu dibenarkan (direalisasikan) atau didustakan (tidak direalisasikan) oleh kemaluannya. ${ }^{18}$

Penjelasan dari hadis tersebut bahwa zina mata adalah memandang yaitu seseorang jika melihat wanita yang bukan mahramnya maka termasuk zina mata. Apalagi menonton tayangan tayangan wanita yang terbuka auratnya atau film dewasa atau melihat majalah dewasa dan sebagainya. Hadis ini mengisyaratkan larangan untuk terikat dengan wanita (yang bukan mahramnya) yaitu dengan suaranya, memandang kepadanya, menyentuhnya, berjalan ke arahnya, dan juga keinginan dan angan-angan terhadapnya. Oleh karena itu, manusia yang berakal dan menjaga harga dirinya berhati-hati terhadap anggota

18 HR. Bukhari No. 6243, HR. Muslim No. 2657 dan Ahmad II/276, Shahih Bukhari dan Shahih Muslim.

Sangaji Jurnal Pemikiran Syariah dan Hukum 
tubuhnya agar tidak terikat dengan wanita selain istri dan budaknya. ${ }^{19}$

\section{Pandangan Para Ulama Mengenai Suami Istri yang Menonton Video Dewasa}

Perkara kebolehan atau larangan melihat video dewasa bagi pasangan suami istri merupakan sebuah masalah kontemporer. Perkembangan teknologi dan informasi termasuk kecanggihan alat komunikasi tidak didapati pada masa awal Islam hingga masa klasik. Namun, pada masa tersebut telah ada beberapa aturan yang mengatur mengenai patung dan gambar. Seperti hadis berikut:

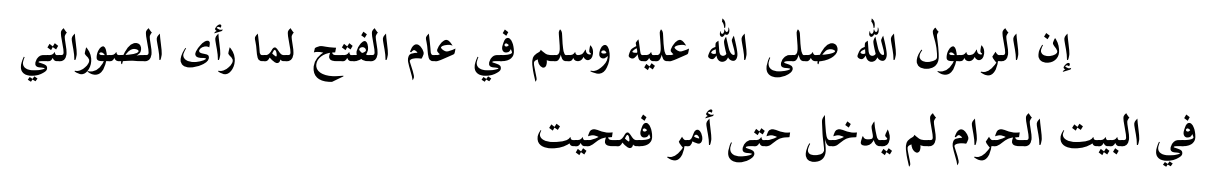

Artinya:

"Sesungguhnya Rasulullah saw pada waktu tahun penaklukan Mekah melihat patung-patung di dalam Baitullah, maka ia tidak masuk sehingga ia menyuruh kemudian menghancurkannya." (HR. Bukhari)

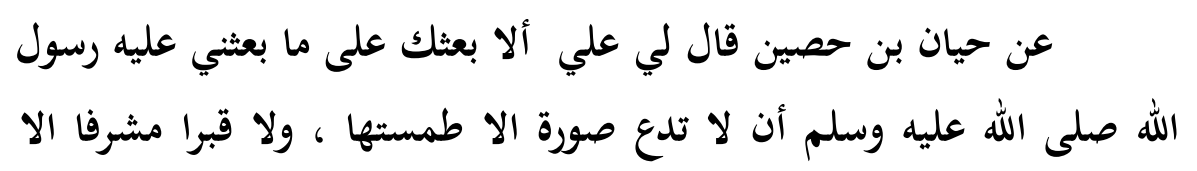

سويته

Artinya:

Dari Hayyan bin Hushain, ia berkata Ali kepadaku: Ingatlah! Tidakkah mengirimmu sebagaimana Rasulullah Saw., mengirim aku yaitu hendaknya jangan kau biarkan sebuah patung kecuali harus dihancurkan dan jangan kau biarkan

${ }^{19}$ Imam An-Nawawi, Syarh Shahih Muslim (Bab XVI, t.ket), h, 206. 
sebuah kubur (yang berkuncup), kecuali harus diratakan. (HR. Muslim)

Beberapa ulama berpendapat bahwa patung yang di larang yang dimaksudkan oleh hadis tersebut yaitu patung yang bertujuan untuk disembah, diagung-agungkan, ditinggikan atau untuk menyerupai dan menandingi ciptaan Allah Swt. Adapun fotografi pada prinsipnya mubah selama tidak mengandung objek yang diharamkan atau untuk tujuan seperti disebutkan sebelumnya. ${ }^{20}$

Mengenai video dewasa, ada beberapa pendapat yang dikemukakan oleh para ulama mengenai hukum dari melihat video tersebut bagi pasangan suami istri. Namun perlu ditekankan bahwa video dewasa belum di kenal pada masa ulama klasik sehingga hukum yang dibicarakan hanya berkisar tentang gambar dan patung saja.

Terdapat beberapa pendapat mengenai melihat video dewasa ini. Pendapat yang pertama mengatakan bahwa melihat film dewasa bagi pasangan suami-istri diperbolehkan. Pandangan ini dirujukkan kepada apa yang dikemukakan oleh Syihabuddin al-Qalyubi. Beliau berpendapat bahwa haram melihat sesuatu dari anggota badan perempuan ajnabiyyah, meskipun itu sudah terpisah darinya, seperti kuku atau rambut kemaluannya. Keharaman melihat ini juga meliputi melihatnya dari balik kaca atau kain tenun yang tipis atau dalam air yang jernih. Namun jika melihat sosok yang terpantul dari dalam air atau cermin tidaklah diharamkan walaupun disertai dengan syahwat. ${ }^{21}$ Adapun video dewasa diqiyaskan dengan tayangan

20 Syekh Muhammad Yusuf Qardhawi, Halal dan Haram dalam Islam (Surabaya: PT. Bina Ilmu Surabaya, 2010), h. 158.

21 NU Online, Bolehkah Suami-Istri Menonton Film Porno? , www.nu.or.id/post/read/54004/bolehkah-suami-istri-menonton-film-porno, diakses pada tanggal 5 April 2017, pkl. 14.24 WITA.

Sangaji Jurnal Pemikiran Syariah dan Hukum 
yang merupakan hasil dari pantulan cermin sehingga aurat tidak dilihat secara langsung.

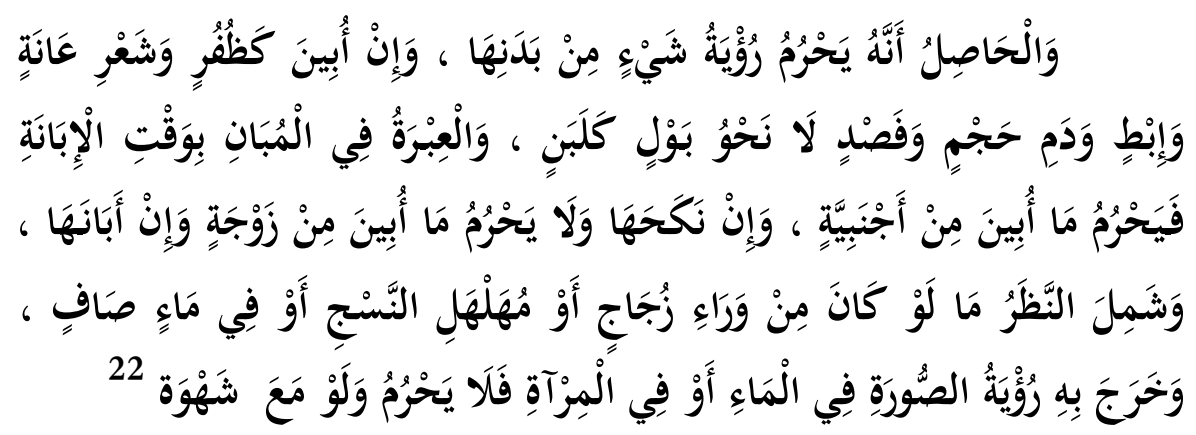

Kesimpulannya, bahwa haram melihat sesuatu dari anggota badan perempuan ajnabiyyah meskipun dipisahkan, seperti kuku, rambut kemaluan, bulu ketiak, darah bekam, darah yang keluar dengan cara membelah pembulu darah vena (fashd), bukan semisalnya air kencingnya dan air susu. Oleh karena itu, haram apa yang terpisah dari perempuan ajnabiyyah meskipun sudah pernah dinikahi, dan tidak haram apa yang dipisahkan dari istrinya sekalipun suaminya memisahkannya. Melihat dalam konteks ini termasuk melihat sesuatu dari anggota badan perempuan ajnabiyyah dari balik kaca atau kain tenun yang tipis atau air yang jernih. Dan terkecualikan dari melihat aurat perempuan ajnabiyyah adalah melihat sosok yang terpantul dari dalam air atau cermin".

Pendapat lain yang menyatakan bahwa melihat sesuatu (al-manzhur ilaih) seperti mahram atau selain istri, jika menimbulkan syahwat adalah haram. Bahkan keharaman ini menurut Ali asy-Syibramalisi mencakup juga keharaman melihat benda-benda mati (al-jamadat).

${ }^{22}$ Syihabuddin al-Qalyubi, Hasyiyah al-Qalyubi (juz 3; Bairut-Dar al-Fikr, 1419 H/1998 M), h. 2019. 


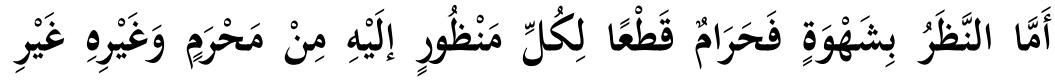

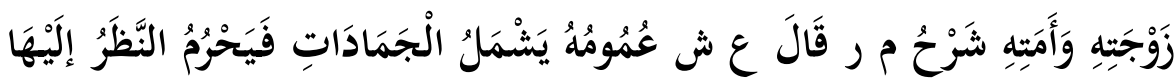 \\ بشََْْهُوَة 23}

Maksudnya pendapat tersebut bahwa melihat sesuatu (al-manzhur ilaih) seperti mahram dan selainnya, selain istri dan budaknya, secara pasti adalah haram (Syarah Muhammad arRamli). (Dalam hal ini) Ali asy-Syibramalisi menyatakan bahwa keumuman keharaman ini meliputi benda-benda mati. Oleh karena itu, haram melihat benda-benda mati dengan disertai syahwat. Dengan mengacu kepada pandangan yang kedua, maka menonton film dewasa bagi suami-istri adalah haram. Sebab, melihat benda mati saja jika disertai dengan syahwat itu hukumnya haram, apalagi melihat film dewasa. Pendapat inilah yang dipegangi oleh Lajnah Bahtsul Masail (LBM) NU. ${ }^{24}$

Fatwa Majelis Tarjih dan Tajdid (MTT) Muhammadiyah menyatakan keharaman dewasagrafi dan dewasaaksi sesuai dengan Alquran, sunnah al-Maqbūlah dan beberapa kaidah fikih. Adapun untuk kepentingan medis, hukumnya adalah mubah sesuai dengan kaidah fikih: ${ }^{25}$

\section{الحاجة تنزل منزلة الضرورة عامة أو خاصة}

Maksudnya:

23 Sulaiman al-Bujairimi, at-Tajrid li Naf' al-'Abid juz 3 (Turki: alMaktabah al-Islamiyyah, tt), h. 326.

24 NU Online, Bolehkah Suami-Istri Menonton Film Porno? , www.nu.or.id/post/read/54004/bolehkah-suami-istri-menonton-film-porno, diakses pada tanggal 5 April 2017, pkl. 14.24 WITA.

25 Muhammadiyah Online, Pornografi, www.fatwatarjih.com/2011/08/pornografi.html?m=1, diakses pada tanggal 7 April 2017, pkl. 23.24 WITA.

Sangaji Jurnal Pemikiran Syariah dan Hukum 
"Sebuah hajat (kebutuhan), baik umum atau khusus bisa menempati posisi darurat." 26

Namun pendapat MTT Muhammadiyah ini tidak menyebutkan secara spesifik bahwa hukum ini berlaku bagi suami istri atau perorangan secara umum. Namun agaknya hukum ini diberlakukan secara umum disebabkan tidak adanya kekhususan dari redaksi putusan tersebut.

\section{Kedudukan Hukum Bagi Pasangan Suami Istri yang Menonton Video Dewasa}

Kedudukan hukum melihat atau menonton video dewasa bagi suami istri terbagi atas dua pendapat sesuai dengan pendapat ulama. Ada yang berpendapat hukumnya haram adapula yang menghukumi mubah. Dalam menetapkan hukum terhadap suatu perkara harus merujuk pada dalil-dalil dan mempertimbangkan pendapat dari ulama terdahulu sebagai dasar untuk menetapkan hukum yang muncul di masa kontemporer ini.

Melihat video dewasa bagi suami istri hukumnya haram didasarkan pada QS. Al Nur ayat 30-31. Ayat ini memerintahkan untuk menjaga pandangan yang berlaku baik laki-laki dan perempuan tanpa memperhatikan apakah keduanya dalam hubungan sebagai suami istri atau tidak. Hukum ini merupakan hukum 'ainiyah (berlaku perorangan) tanpa memandang relasi kekeluargaan dan sejenisnya. Hubungan suami istri tidak kemudian menghalalkan semua yang haram sebelum terjadinya akad nikah seperti berhubungan badan, melihat aurat suami atau istri, dan sebagainya. Hubungan suami istri tidak berimplikasi pada kebolehan melihat aurat wanita/pria ajnabiyah sekalipun untuk kepentingan hubungan suami istri tersebut.

26 Abbas Arfan, 99 Kaidah Fiqh Muamalah Kulliyah (Malang: UIN Maliki Press, 2013), h. 61. 
Kedudukan menonton video dewasa dapat diqiyaskan pada perbuatan melihat aurat laki-laki atau perempuan yang bukan muhrim. Hal ini karena melihat dengan perantaraan media baik cermin, layar televisi, layar handphone dan sebagainya bisa dikatakan sama dengan melihat secara langsung. Proses melihat ini memunculkan ilusi dan halusinasi dalam otak manusia sehingga menimbulkan efek bangkitnya syahwat. Hal ini meyebabkan dihukumi haram karena statusnya sama dengan berzina sebagaimana dalam hadis riwayat Bukhari yang telah disebutkan. Dengan demikian pendapat dari Syihabuddin al-Qalyubi dapat dibantahkan karena melihat dalam konteks ini tidak hanya mempertimbangkan aktivitas lahiriyah dari memandang melainkan efek dari memandang tersebut.

Ada pula yang menyebutkan alasan pembenaran mengenai kebolehan melihat video dewasa bagi suami istri. Pendapatnya beralasan bahwa yang dicegah dari aktivitas tersebut yaitu menjurusnya pada zina yang boleh jadi dilakukan oleh seseorang yang tidak memiliki suami atau istri. Adapun bagi yang telah menikah maka kemungkinan zina itu tidak akan terjadi karena telah tersedia sarana penyaluran syahwat tersebut. Namun alasan ini tidak mampu menggugurkan hukum haram memandang aurat yang bukan mahramnya.

Adapun dalil maslahat mursalah untuk mendapatkan manfaat bagi manusia dalam arti memberi keuntungan atau kesengangan ${ }^{27}$ yang digunakan untuk membenarkan aktivitas melihat video dewasa untuk kepentingan kepuasan dalam hubungan suami istri tidak dapat dibenarkan karena maslahat tersebut tidak bertujuan untuk menghindari kemudharatan.

${ }^{27}$ Amir Syarifuddin, Ushul Figh 2 (Cet. VII; Jakarta: Prenadamedia Grup, 2014), h. 368.

Sangaji Jurnal Pemikiran Syariah dan Hukum 
Tanpa melihat video dewasa sebelum berhubungan, aktivitas tersebut pun tetap dapat dilakukan.

Dalam beberapa kasus, penyakit ketikmampuan berhubungan tanpa adanya rangsangan sebelumnya, juga dijadikan sebagai alasan pembenaran. Namun secara akal sehat hal ini tidak dapat dibenarkan karena telah diberikan jalan dengan memperbolehkan untuk memandang aurat istri atau suami secara langsung sebagaimana QS. Al Nūr ayat 31 “... kecuali kepada suami mereka,...". Secara logis, memandang langsung, meraba dam sebagainya terhadap objek yang dimiliki oleh istri jauh lebih dapat mendatangkan rangsangan dibandingkan dengan hanya melihat melalui media video.

Terdapat sebuah jalan yang memungkinkan status dari haram menjadi mubah apabila video dewasa tersebut dibuat oleh suami istri itu sendiri dalam arti taken by self yang menampilkan suami istri itu sendiri bukan orang lain. Pendapat ini didasarkan pada kebolehan suami melihat aurat istri bahkan sampai pada aurat yang tidak pantas dan etis untuk dilihat oleh orang-orang yang disebutkan dalam QS. Al Nūr ayat 31 seperti paha, farji, dan sebagainya. Video yang dibuat sendiri menampilkan aurat suami dan istri yang mereka boleh saling melihat baik secara langsung ataupun melalui media.

Meskipun dibolehkan, namun harus ditegaskan bahwa video tersebut hanya konsumsi pribadi. Suami istri tersebut juga harus menjaga kerahasiaan dari hubungan mereka jangan sampai video tersebut tersebar dan ditonton oleh orang lain. Hal ini mengingat beberapa kasus yang terjadi ketika dua orang melakukan hubungan intim kemudian direkam namun oleh pihak yang berniat buruk kemudian menyebarluaskan video tersebut, maka akan menimbulkan kemudharatan. Dalam salah satu hadis, Rasulullah Saw. bersabda: 


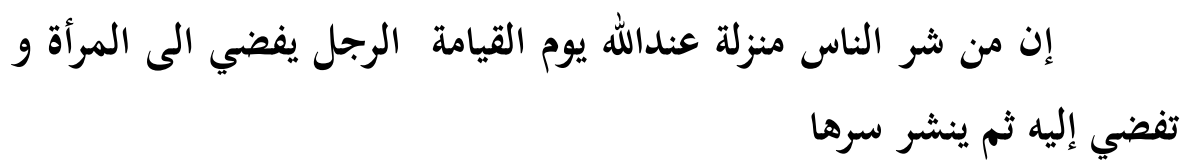

Artinya:

"Sesungguhnya di antara sejelek-jelek manusia dalam pandangan Allah nanti di hari kiamat ialah seorang laki-laki yang menyetubuhi istrinya dan istripun melakukan persetubuhan kemudian dia menyiar-nyiarkan rahasianya." (HR. Muslim dan Abu Daud) $)^{28}$

Oleh karena itu, suami istri harus tetap wasapada dalam setiap aktivitasnya agar mampu menyembunyikan rahasiarahasia hubungan mereka. Terkadang sesuatu yang diniatkan untuk kebaikan ternyata justru disalahgunakan oleh pihakpihak lain yang tidak bertanggung jawab.

\section{E. Kesimpulan}

Pengertian video dewasa bukan sekedar tayangan televisi saja namun seluruh gambar bergerak berupa film, anime, vlog, atau tayangan lainnya yang menampilkan aurat seseorang. Tayangan tersebut sampai menampilkan aktivitas intim dari laki-laki dan perempuan (boleh jadi dua orang atau lebih) yang mampu membangkitkan syahwat (nafsu birahi). Tayangan dewasa seperti ini dijadikan sebagai media untuk membangkitkan syahwat yang berujung pada kegiatan seksual suami istri. Dalil-dalil yang mengatur hal tersebut antara lain QS. Al Rūm: 21, QS. Al Nūr: 30-31, dan HR. Bukhari No. 6243 dan HR. Muslim No. 2657.

Terdapat beberapa pendapat mengenai melihat video dewasa ini. Pendapat yang pertama mengatakan bahwa melihat film dewasa bagi pasangan suami-istri diperbolehkan

\footnotetext{
28Syekh Muhammad Yusuf Qardhawi, Halal dan Haram dalam Islam, h.
} 272.

Sangaji Jurnal Pemikiran Syariah dan Hukum 
sebagaimana dikemukakan oleh Syihabuddin al-Qalyubi. Ali asy-Syibramalisi menyatakan perkara tersebut haram. Pendapat ini juga yang dipegangi oleh Lajnah Bahtsul Masail (LBM) NU. Adapun Fatwa Majelis Tarjih dan Tajdid (MTT) Muhammadiyah menyatakan keharaman dewasagrafi dan dewasaaksi sesuai dengan Alquran, sunnah al-Maqbūlah dan beberapa kaidah fikih.

Melihat video dewasa bagi suami istri hukumnya haram didasarkan pada QS. Al Nūr: 30-31. Ayat ini memerintahkan untuk menjaga pandangan yang berlaku baik laki-laki dan perempuan tanpa memperhatikan apakah keduanya dalam hubungan sebagai suami istri atau tidak. Hukum ini merupakan hukum 'ainiyah (berlaku perorangan) tanpa memandang relasi kekeluargaan dan sejenisnya. Terdapat sebuah jalan yang memungkinkan status dari haram menjadi mubah apabila video dewasa tersebut dibuat oleh suami istri itu sendiri dalam arti taken by self yang menampilkan suami istri itu sendiri bukan orang lain.

\section{F. Implikasi}

Persoalan dewasagrafi dan dewasaaksi adalah suatu pembahasan yang urgen dalam kehidupan bermasyarakat umat Islam. Banyak masalah yang terjadi setelah beredarnya video atau tayangan dewasa tersebut contohnya kasus pemerkosaan, kekerasan seksual, tindakan asusila, dan sebagainya. Beberapa penelitian menunjukkan bahwa asal dari berbagai masalah tersebut adalah dari rangsangan media baik cetak maupun elektronik.

Walaupun demikian, ada pula pihak yang merasa terbantu dengan adanya tayangan semacam ini misalnya suami istri. Menonton video dewasa bagi mereka ternyata mampu memberikan kepuasan tersendiri dalam berhubungan. Namun bila dilihat secara seksama, maka dapat dilihat bahwa banyak 
dalil yang melarang kegiatan tersebut. Hal ini berimplikasi pada penetapan hukum haram terhadap tontonan dewasa bagi suami istri. Namun dalam keadaan-keadaan tertentu, hal ini dapat dibolehkan asalkan alasan tersebut dinilai syar'i dan untuk menghindari kemudharatan.

\section{Daftar Pustaka}

Abbas Arfan. 99 Kaidah Figh Muamalah Kulliyah. Malang: UIN Maliki Press, 2013.

Amir Syarifuddin. Ushul Figh 2. Cet. VII; Jakarta: Prenadamedia Grup, 2014.

Imam An-Nawawi. Syarh Shahih Muslim . Bab XVI, t.ket.

Kementerian Agama RI. Aplikasi Qur'an Kemenag. Jakarta: Lajnah Pentashihan Mushaf Al-Qur'an, 2016.

Kementerian Pendidikan dan Kebudayaan RI. Aplikasi Kamus Besar

Bahasa Indonesia Edisi Kelima. Jakarta: Badan Pengembangan dan Pembinaan Bahasa Kemendikbud, 2016.

M. Quraish Shihab. Tafsīr Al-Mishbāh volume 8. Jakarta: Penerbit Lentera Hati, 2009.

M. Quraish Shihab. Tafsīr Al-Mishbāh volume 10. Jakarta: Penerbit Lentera Hati, 2009.

NU Online, Bolehkah Suami-Istri Menonton Film Dewasa? , www. nu.or.id/ post/read/54004/bolehkah-suami-istri-menontonfilm-dewasa, diakses pada tanggal 5 April 2017, pkl. 14.24 WITA.

Sulaiman al-Bujairimi. at-Tajrid li Naf' al-'Abid juz 3. Turki: alMaktabah al-Islamiyyah, tt.

Sangaji Jurnal Pemikiran Syariah dan Hukum 
As-Suyuthi. al-Asyba' wan nhadhair . t.t.: t.tp, t.th.

Syekh Muhammad Yusuf Qardhawi. Halal dan Haram dalam Islam. Surabaya: PT. Bina Ilmu Surabaya, 2010.

Syihabuddin al-Qalyubi. Hasyiyah al-Qalyubi. Bairut-Dar al-Fikr, 1998.

Tim Penyusun Ensiklopedia Hukum Islam. Ensiklopedia Hukum Islam 4. Jakarta: PT. Ichtiar Baru Van Hoeve, 1997. 